\title{
Gastric enterochromaffin-like (ECL) cells in hypergastrinaemic duodenal ulcer disease
}

\author{
M Coupe, H Rees, C J Springer, A E Bishop, J A Morris, J M Polak, J Calam
}

\begin{abstract}
Patients with hypergastrinaemic duodenal ulcer disease were studied to determine whether chronic moderate hypergastrinaemia produces hyperplasia of gastric enterochromaffin-like cells in man. Eight patients had peak postprandial plasma gastrin concentrations $>200 \mathrm{pmol} / \mathrm{l}$, which is the 92nd percentile for patients with duodenal ulcer disease in this laboratory. The control group was eight patients with duodenal ulcers whose peak postprandial gastrin concentrations were $<200 \mathrm{pmol} / \mathrm{l}$. Basal and peak postprandial plasma gastrin concentrations were 107 (37) and $306(66) \mathrm{pmol} / \mathrm{l}$ (mean (SEM)) respectively in the hypergastrinaemic patients compared with 26 (4) and 137 (14) pmol// respectively in the controls. There was no significant difference in the density of gastrin enterochromaffin-like cells between the two groups. The number of enterochromaffin-like cells per high power field was $53(8)$ in the hypergastrinaemic patients compared with 50 (8) in the controls. We conclude that chronic moderate hypergastrinaemia does not produce hyperplasia of enterochromaffin-like cells in man. Our hypergastrinaemic group had plasma gastrin concentrations similar to, or greater than those reported during treatment with drugs such as omeprazole and histamine $\mathbf{H}_{2}$ receptor blockers.
\end{abstract}

Human gastric mucosa contains enterochromaffin-like cells which are the major progenitors of carcinoid tumours at this site. Some patients with pernicious anaemia develop gastric enterochromaffin-like cell hyperplasia, and a few develop gastric carcinoid tumours. ${ }^{1-}$ The trophic effect of gastrin which circulates in high concentrations in the absence of gastric acid may be responsible for these changes. Experimental animals also develop enterochromaffin-like hyperplasia and gastric carcinoid tumours during prolonged suppression of gastric acid secretion with some new drugs including omeprazole ${ }^{56}$ and loxtidine. ${ }^{7}$

These changes could be important in relation to the treatment of peptic ulcer disease but there have been few studies of enterochromaffin-like cells in such patients. Hypergastrinaemia occurs during inhibition of gastric acid secretion with cimetidine, ranitidine, ${ }^{8}$ and omeprazole. ${ }^{9-11}$ Hypergastrinaemia of a similar degree, but of longer duration, occurs in a subgroup of patients with duodenal ulcer disease. ${ }^{1213} \mathrm{We}$ therefore compared gastric enterochromaffinlike cell density in a group of these patients and a group of normogastrinaemic duodenal ulcer patients.

\section{PATIENTS}

\section{Methods}

The study was approved by the hospital ethics committee and all subjects gave informed consent.

In a preliminary study of 50 patients with duodenal ulcer disease, the mean peak postprandial gastrin concentration was $106 \mathrm{pmol} / \mathrm{l}$ with a range of 29-584 pmol/1. Four patients had peak postprandial serum gastrin concentrations $>200 \mathrm{pmol} / \mathrm{l}$. These four patients, plus two with peak levels $>180 \mathrm{pmol} / \mathrm{l}$, were reinvestigated together with 10 other patients with known duodenal ulcer disease. No patient had taken any medication the two weeks before the study and none had undergone gastrointestinal surgery or vagotomy.

Patients fasted overnight before admission to a programmed investigation unit. A cannula was inserted into a forearm vein and blood samples taken over a 24 hour period for gastrin assay. Subjects consumed a standard diet during this period, starting with a standard breakfast consisting of two eggs, two rounds of dry toast and a cup of beef extract (two cubes of Oxo, Brooke Bond OxO Ltd, Croydon, UK).

On the following morning gastroscopy was performed and six biopsies were taken, using Olympus FB-25K biopsy forceps, from the greater curve of the stomach $55 \mathrm{~cm}$ from the teeth.

Biopsies were fixed in Bouin's solution and processed to wax. Sections were stained with haematoxylin and eosin. In addition, sections were stained by Grimelius' method (silver impregnation for enterochromaffin-like and enterochromaffin cells) and immunostained using the peroxidase antiperoxidase technique ${ }^{14}$ with rabbit antiserum to serotonin donated by Dr J De Mey, to stain enterochromaffin cells, ${ }^{15}$ an antiserum to somatostatin purchased from RIA (UK) Ltd (Washington, Tyne \& Wear, UK) to stain D cells, ${ }^{15}$ and the entire endocrine cell population was demonstrated with monoclonal mouse antibodies to chromogranin donated by Dr R V Lloyd ${ }^{15}{ }^{16}$ (Fig 1). Nucleated, stained cells were counted using a light microscope with a high power field aligned so that one edge lay against the muscularis mucosae and the full depth of the mucosa was scanned. As no specific stain exists for the enterochromaffin-like cells, a subtracting method was used. Enterochromaffin cell numbers (serotonin-immunoreactive) were subtracted from the number of Grimelius-positive cells and both enterochromaffin and D (somatostatin-immunoreactive) cell numbers were subtracted from the total of chromogranin-immunoreactive cells. In all cases, the latter method of calculation gave higher enterochromaffin-like cell numbers, probably 
Figure 1: Gastric biopsy immunostained with antibodies to chromogranin and counterstained with weak haematoxylin. Enterochromaffin-like cells are distinguished by their characteristic localisation along the basement membrane and lack of lumenal contact.

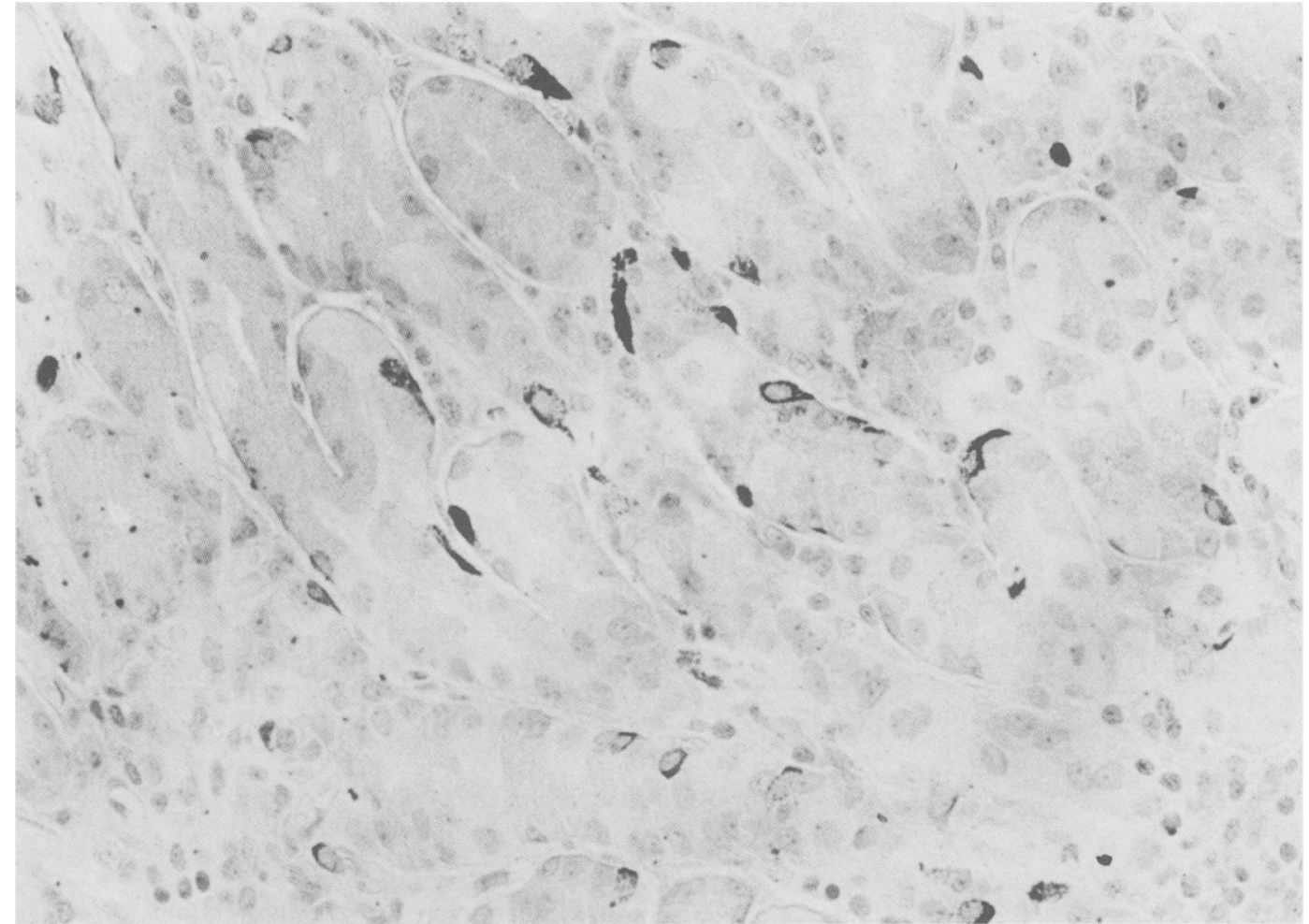

because of the sensitivity of the staining methods, and was used to obtain the final figures.

Blood samples for gastrin assay were collected into chilled tubes containing EDTA $(5 \mathrm{mmol} / \mathrm{l}$ blood), plasma separated at $4^{\circ} \mathrm{C}$, and stored at $-20^{\circ} \mathrm{C}$ until assay. Gastrin was measured by radioimmunoassay based on gastrin specific antiserum 1611 donated by $\mathrm{Dr} \mathrm{J} \mathrm{H}$ Walsh, using published methods. ${ }^{17}$ Some subjects also had a standard pentagastrin test performed on another day, using an intravenous infusion of pentagastrin, $6 \mu \mathrm{g} / \mathrm{kg} / \mathrm{h}$, with intragastric phenol red to correct for pyloric losses. ${ }^{18}$

STATISTICAL ANALYSIS

Statistical analysis was by Student's $t$ test and linear regression. $P<0.05$ was taken to be statistically significant.

\section{Results}

The median peak postprandial gastrin concentration was $200 \mathrm{pmol} / \mathrm{l}$. We therefore compared the eight patients with 'high gastrin' (peak $>200 \mathrm{pmol} / \mathrm{l}$ ) with the eight patients with 'low gastrin' (peak $<200 \mathrm{pmol} / \mathrm{l}$ ). The 'high gastrin' group contained three men and five women and had a mean age of 46 years (range 3955). The 'low gastrin' group contained four men and four women and had a mean age of 52 years (range 28-60). Plasma gastrin had been measured in 10 of the patients at least three years before the present study. Peak postprandial gastrin concentrations in six of the patients in the 'high gastrin' group and four of the patients in the 'low gastrin' group were 288 (99) and 84 (30) pmol/1 (mean (SEM)) respectively in the previous study.

Five members of each group had pentagastrin tests. Basal acid output was 5 (2) and 3 (1) $\mathrm{mmol} / \mathrm{h}$ respectively (NSD) and peak acid output was
49 (6) and $55(8) \mathrm{mmol} / \mathrm{h}$ respectively (NSD) in the 'high' and 'low gastrin' groups.

The 24 hour gastrin profiles for the two groups are shown in Figure 2. As expected, plasma gastrin concentrations were significantly different between the two groups at every time point during the 24 hour period. The means of gastrin concentrations throughout the day were also significantly different (Table).

Despite the difference in serum gastrin, the number of enterochromaffin-like cells per high power field were not significantly different in the two groups. The mean enterochromaffin-like cell counts in the 'high' and 'low gastrin' groups were 53 (8) and 50 (8) per high power field respectively. In addition, linear regression analyses of enterochromaffin-like cells/high power field against peak postprandial gastrin, mean daily gastrin and fasting gastrin concen-

\section{Discussion}

In this study, we compared gastric enterochromaffin-like cell density and circulating gastrin concentrations in patients with hypergastrinaemic and normogastrinaemic duodenal ulcer disease. Our results indicate that hypergastrinaemia is not associated with gastric enterochromaffin-like cell hyperplasia.

Enterochromaffin-like cell hyperplasia and gastric carcinoid tumours occur both in experimental animals during inhibition of gastric acid secretion ${ }^{5-7}$ and in patients with pernicious anaemia. ${ }^{1-4}$ This is generally believed to be caused by hypergastrinaemia which occurs in the absence of gastric acid, ${ }^{19}$ although the evidence for this is indirect, and has been disputed by Penston and Wormsley. ${ }^{20}$ Perhaps the strongest evidence for the role of gastrin in enterochromaffin-like cell hyperplasia comes from studies trations showed no significant correlations. 
Figure 2: Plasma gastrin concentrations during a $24 h$ period in patients with ' high' gastrin (peak >200 pmol/l) and 'low' gastrin (peak $<200$ pmolll). $\mathbf{0}=$ 'high' gastrin and $\mathrm{O}=$ 'low' gastrin, mean (SEM), $M$ indicates meals.

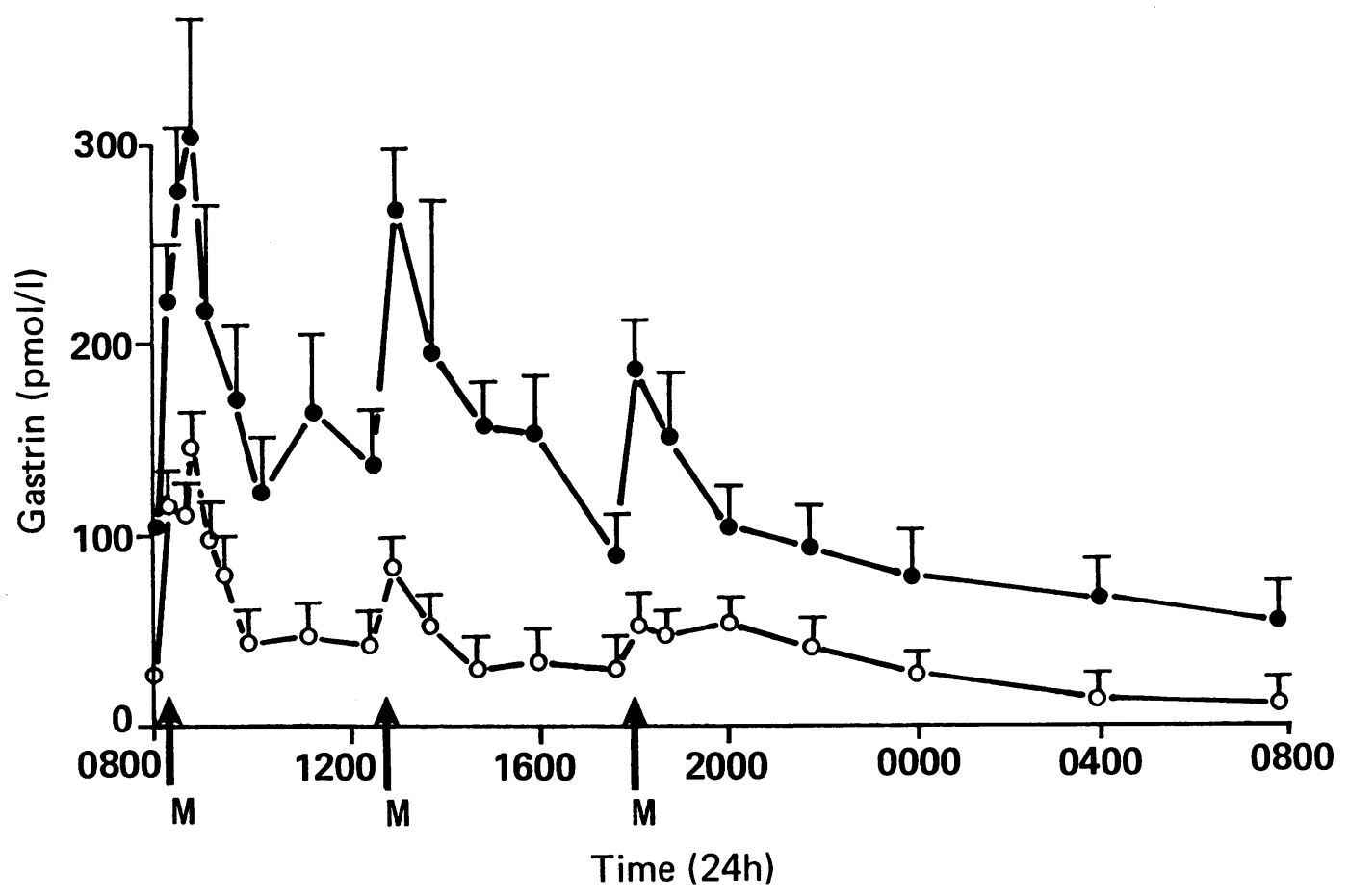

which show that antrectomy prevents enterochromaffin-like cell hyperplasia in rats treated with omeprazole. ${ }^{21}$ Antrectomy also led to regression of gastric carcinoid tumours in a patient with pernicious anaemia. ${ }^{22}$ In these situations, it could still be argued that the lack of gastric acid, rather than the hypergastrinaemia produces enterochromaffin-like cell hyperplasia. Hyperplasia of enterochromaffin-like cells has, however, also been reported in patients with gastrin secreting tumours, without therapeutic suppression of gastric acid secretion..$^{23-26}$

The main concern is that newer treatments of peptic ulcer disease might cause enterochromaffinlike cell hyperplasia and gastric carcinoid tumours. This is difficult to resolve because hypergastrinaemia may have to be prolonged to affect enterochromaffin-like cells. We undertook the current study having observed that the hypergastrinaemia of antral origin in patients with duodenal ulcer persists for years. ${ }^{12}$ In the present study, plasma gastrin concentrations were consistent over a three year period. Hypergastrinaemic duodenal ulcer patients typically have basal and postprandial plasma gastrin concentrations about two or three times the mean of those found in duodenal ulcer patients as a whole. This may be compared with a rise in plasma gastrin concentrations by about $60 \%$ on ranitidine $150 \mathrm{mg}$ bid and cimetidine $300 \mathrm{mg}$ qid, ${ }^{8}$ about $30 \%$ on omeprazole $20 \mathrm{mg}$ daily,

TABLE Basal, peak postprandial and mean $24 \mathrm{~h}$ plasma gastrin concentrations and gastric ECL cell density in duodenal ulcer patients with 'high' and 'low' plasma gastrin concentrations

\begin{tabular}{llll}
\hline & 'High' gastrin & 'Low' gastrin & p Value \\
\hline $\begin{array}{l}\text { Plasma gastrin } \\
\text { (pmol/l) }\end{array}$ & & & \\
Basal & $107(37)$ & $26(4)$ & $<0.05$ \\
Peak postprandial & $306(66)$ & $137(14)$ & $<0.05$ \\
Mean diurnal & $156(30)$ & $57(8)$ & $<0.05$ \\
Enterochromaffin-like cell density & $53(8)$ & $50(8)$ & NSD \\
(cells/high power field) & & & \\
\hline
\end{tabular}

(Mean $($ SEM)). about $100 \%$ on omeprazole $30 \mathrm{mg}$ daily ${ }^{10}$ and about $150 \%$ on omeprazole $40-60 \mathrm{mg}$ daily." Our results suggest that prolonged hypergastrinaemia of this order will be insufficient to cause enterochromaffin-like cell hyperplasia. This is consistent with the lack of change in enterochromaffin-like cell density reported by Lamberts et al in patients treated with omeprazole 40-60 mg daily for 12-24 months. "It should be noted that enterochromaffin-like cell hyperplasia has only been reported in man in association with conditions which produce much higher plasma gastrin concentrations. Gastrin concentrations in pernicious anaemia and the Zollinger Ellison syndrome are usually at least 10 times and often more than 100 times higher than normal levels. ${ }^{27}$

Although our results suggest that newer treatment of peptic ulcer disease will not produce gastric enterochromaffin-like cell hyperplasia, further studies are required to determine the threshold plasma gastrin concentrations required to affect gastric enterochromaffin-like cells.

We are grateful to Glaxo Laboratories Ltd for supporting this project. This work was presented at a meeting of the Bayliss and Starling Society in Cambridge in September 1988. The abstract was published in Regulatory Peptides 1988; 22: 397. It was also was published in Regulatory Peptides 1988; 22: 397. It was also presented at the International Congress of Gastroenterology in
Rome in September 1988. Abstract: Gastroenterol Int 1988; Rome in Septem
1(suppl 1): 974 .

1 Larsson L, Rehfeld J, Stockbrugger R, et al. Mixed endocrine tumours associated with hypergastrinaemia of antral origin. Am 7 Pathol 1978; 93: 53-68.

2 Hodges J, Isacsson P, Wright R. Diffuse enterochromaffinlike (ECL) cell hyperplasia and multiple gastric carcinoids; complication of pernicious anaemia. Gut 1981; 22: 237-41.

3 Carney A, Go V, Fairbanks V, Moore S, Alport E, Nova F The syndrome of gastric argyrophil carcinoid tumours and nonantral gastric atrophy. Ann Intern Med 1983; 99: 761-6.

4 Borch K, Renvall H, Liedberg G. Gastric endocrine cell hyperplasia and carcinoid tumours in pernicious anaemia. Gastroenterology 1985; 88: 638-48.

5 Creutzfeldt W, Stockmann F, Conlon J, Folsch U, Bonatz G, omeprazole on rat gastric endocrine cells. Digestion 1985; 35 (suppl 1): 84-97.

6 Ekman L, Hansson E, Havu N, Carlsson E, Lundberg G. Toxicological studies on omeprazole. Scand 7 Gastroenterology 1985; 20 (suppl 108): 53-69. Wulfrath M. Effect of short and long-term feeding of 
7 Poynter D, Pick C, Harcourt R, et al. Association of long lasting unsurmountable histamine $\mathrm{H}_{2}$ blockade and gastric carcinoid tumours in the rat. Gut 1985; 26: 1284-95.

8 Mahachai V, Walker K, Thomson A, et al. Comparison of cimetidine and ranitidine on 24-hour intragastric acidity and
serum gastrin profile in patients with esophagitis. Dig Dis $S_{c i}$ serum gastrin profic

9 Naesdal J, Bankel M, Bodemar G, Gotthard RL, Walan A. The effect of $20 \mathrm{mg}$ omeprazole daily on serum gastrin, 24- $\mathrm{H}$ intragastric acidity, and bile acid concentration in duodenal ulceration. Scand 7 Gastroenterol 1987; 22: $5-12$.

10 Festen $\mathrm{H}$, Thjs J, Lamers C, et al. Effects of oral omeprazole on serum gastrin and serum pepsinogen I levels. Gastroenterology 1984; 87: 1030-43.

11 Lamberts R, Creutzfeldt W, Stockmann F, Jacubaschke S, Maas S, Brunner G. Long-term omeprazole treatment in man: effects on gastric endocrine cell populations. Digestion 1988; 39: 126-35.

12 Taylor IL, Calam J, Rotter JI, et al. Family studies of hypergastrinaemic, hyperpepsinogenemic I duodenal ulcer. Ann Intern Med 1981; 95: 421-5.

13 Freisen S, Tomita T. Further experience with pseudoZollinger-Ellison syndrome: its place in the management of Zollinger-Ellison syndrome: its place in the management of neuroend $652-60$.

14 Sternberger L. The unlabelled antibody peroxidase antiperoxidase (PAP) method. In: Sternberger LA. Immunocytochemistry. New York: Wiley, 1986: $104-69$

15 Facer P, Bishop AE, Lloyd RV, Wilson BS, Hennessey RJ, Polak JM. Chromogranin: a newly recognised marker for endocrine cells of the human gastrointestinal tract. Gastroenterology 1985; 89: 1366-73.

16 Lloyd RV, Wilson BS. Specific endocrine marker defined by a monoclonal antibody. Science 1983; 222: 628-30.
17 Walsh J, Lamers C, Vatenzuela J. Cholecystokininoctapeptidelike immunoreactivity in human plasma. Gastroenterology 1982; 82: 438-44.

18 Baron JH. Clinical tests of gastric secretion. London: MacMillan Press, 1978.

19 Bordi C, Creutzfeldt W, Hakanson R, Solcia E, Sundler F [Letter.] Gut 1987; 28: 1189-90.

20 Penston J, Wormsley K. Achlorhydria: Hypergastrinaemia: carcinoids - a flawed hypothesis? Gut 1987; 28: 488-505.

21 Larsson $\mathrm{H}$, Carlsson $\mathrm{E}$, Mattsson $\mathrm{H}$, et al. Plasma gastrin and gastric enterochromaffin like cell activation and proliferation. Studies with omeprazole and ranitidine in intact and antrectomised rats. Gastroenterology 1986; 90: 391-9.

22 Richards AT, Hinder R, Harrison A. Gastric carcinoid tumours associated with hypergastrinaemia and pernicious anaemia - regression of tumours by antrectomy. $S$ Afr Med 1987; $72: 51-3$.

23 Bordi C, Cocconi G, Togni R, Vezzadini P, Missale G. Gastric endocrine cell proliferation associated with the Zollinger Ellison syndrome. Arch Pathol 1974; 98 : 274-8.

24 Borch K, Renvall H, Liedberg G, Andersen B. Relations between circulating gastrin and endocrine cell proliferation in the atrophic gastric fundic mucosa. Scand $\mathcal{F}$ Gastroenterol 1986; 21: 357-63.

25 Bardram L, Thomsen P, Stadil F. Gastric endocrine cells in omeprazole-treated and untreated patients with the Zollinger-Ellison syndrome. Digestion 1986; 35 (suppl 1): $116-22$.

26 Mignon M, Lehy T, Bonnefond A, Ruszniewski P, Labeille D, Bonfils S. Development of gastric argyrophil carcinoid tumours in a case of Zollinger-Ellison syndrome with primary hyperparathyroidism during long-term antsecretory treatment. Cancer 1987; 59: 1959-62.

27 Yalow RS, Berson S. Radioimmunoassay of gastrin. Gastroenterology 1970; 58: 1-14 